Acta Crystallographica Section C

Crystal Structure

Communications

ISSN 0108-2701

Editor: George Ferguson

\title{
Isochroman derivatives and their tendency to crystallize in chiral space groups
}

\section{Marcin Palusiak, Arno Pfitzner, Manfred Zabel, Sławomir J. Grabowski, Jan Epsztajn and Justyna A. Kowalska}

Copyright (C) International Union of Crystallography

Author(s) of this paper may load this reprint on their own web site provided that this cover page is retained. Republication of this article or its storage in electronic databases or the like is not permitted without prior permission in writing from the IUCr. 
Acta Crystallographica Section C

Crystal Structure

Communications

ISSN 0108-2701

\section{Isochroman derivatives and their tendency to crystallize in chiral space groups}

\author{
Marcin Palusiak, ${ }^{\text {a* }}$ Arno Pfitzner, ${ }^{\text {b Manfred Zabel, }}{ }^{\mathbf{b}}$ \\ Stawomir J. Grabowski, ${ }^{a}$ Jan Epsztajn ${ }^{\mathrm{c}}$ and \\ Justyna A. Kowalska ${ }^{c}$
}

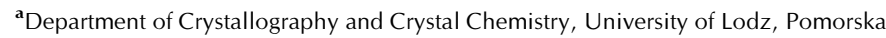
149/153, 90236 Łódź, Poland, 'bInstitut für Anorganische Chemie, Universität Regensburg, 93040 Regensburg, Germany, and ' Department of Organic Chemistry, University of Łódź, Narutowicza 68, 90136 Łódź, Poland

Correspondence e-mail: marcinp@uni.lodz.pl

Received 25 November 2003

Accepted 9 February 2004

Online 11 March 2004

In methyl [5-methoxy-4-(4-methoxyphenyl)isochroman-3-yl]acetate, $\mathrm{C}_{20} \mathrm{H}_{22} \mathrm{O}_{5}$, (I), and methyl [4-(2,5-dimethoxyphenyl)8-methoxyisochroman-3-yl]acetate, $\quad \mathrm{C}_{21} \mathrm{H}_{24} \mathrm{O}_{6}, \quad$ (II), the heterocyclic rings adopt half-chair conformations. The substituents at the 3- and 4-positions are in a trans configuration in both (I) and (II), being in an axial conformation in (I) and in an equatorial conformation in (II). The crystal structure of (I) is stabilized by weak $\mathrm{C}-\mathrm{H}$. . O hydrogen bonding, leading to the formation of an infinite three-dimensional network. Compound (II) crystallizes in a chiral space group. This feature, which was also found in previously investigated isochroman derivatives, is related to the arrangement of substituents attached to the isochroman moiety.

\section{Comment}

Some members of the benzo[c]pyran family have been found in nature and shown to possess a variety of biological properties (Moore, 1977; Moore \& Czerniak, 1981). The title<smiles>COC(=O)CC1OCc2cccc(OC)c2C1c1ccc(OC)cc1</smiles>

(I)<smiles>COC(=O)CC1OCc2c(OC)cccc2C1c1cc(OC)ccc1OC</smiles>

(II) compounds, (I) and (II), were synthesized while searching for new precursors for antibiotics of this type. The present work forms part of a series of systematic X-ray investigations of isochroman derivatives (Palusiak et al., 2002a,b; Palusiak,

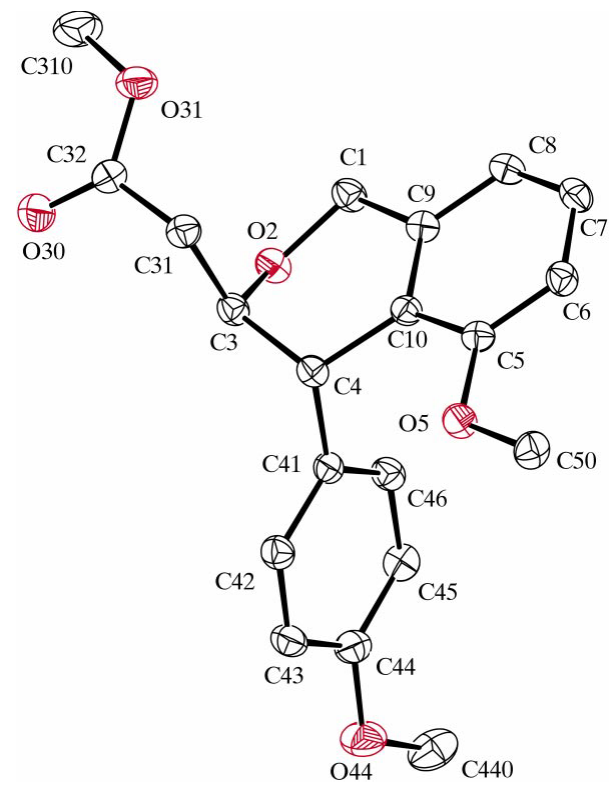

Figure 1

A view of (I) (40\% probability displacement ellipsoids). $\mathrm{H}$ atoms have been omitted for clarity.

Małecka, Rybarczyk-Pirek et al., 2003; Palusiak, Grabowski et al., 2003).

In the molecules of the title compounds (Figs. 1 and 2), the base isochroman moiety is a system of two condensed rings, viz. a benzene ring and a heterocyclic ring with an $\mathrm{O}$ atom at the 2-position. In both compounds, there is a methoxycarbonylmethyl substituent at the 3-position. The molecules differ from each other in the positions of the methoxy groups attached to the benzene ring of the isochroman moiety and in the substituent at the 4-position. In each case, the heterocyclic ring adopts a half-chair conformation, with a twofold axis passing through the mid-point of the $\mathrm{O} 2-\mathrm{C} 3$ bond. The asymmetry parameter (Nardelli, 1983) $\Delta_{2}(\mathrm{O} 2-\mathrm{C} 3)$ is 0.0446 (6) and 0.0124 (7) for (I) and (II), respectively. The puckering parameters (Cremer \& Pople, 1975) $Q, \varphi_{2}$ and $\theta_{2}$ corresponding to the sequence of atoms $\mathrm{O} 2 / \mathrm{C} 3 / \mathrm{C} 4 / \mathrm{C} 10 / \mathrm{C} 9 / \mathrm{C} 1$ are 0.487 (2) $\AA, 17.7$ (2) ${ }^{\circ}$ and 51.9 (2) ${ }^{\circ}$ for the molecule of (I),

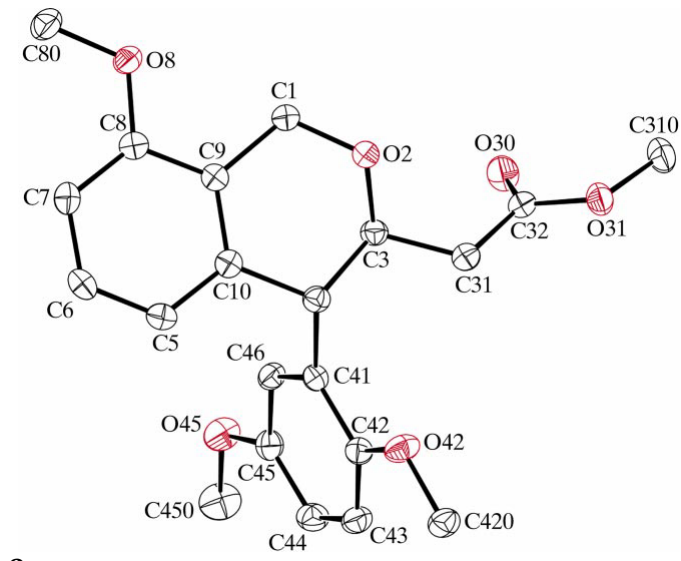

Figure 2

A view of (II) (40\% probability displacement ellipsoids). $\mathrm{H}$ atoms have been omitted for clarity. 
and $0.506(2) \AA, 32.64(3)^{\circ}$ and $50.6(2)^{\circ}$ for the molecule of (II). As in the previously investigated isochromans, the substituents at the 3- and 4-positions are in trans configurations, being in an axial conformation in (I) and in an equatorial conformation in (II). Torsion angles describing these features are presented in Tables 1 and 3 .

Molecules of both (I) and (II) have two chiral centres, at atoms $\mathrm{C} 3$ and $\mathrm{C} 4$. In the case of (I), which crystallizes in a centrosymmetric space group, the relative stereochemistry is $3 S, 4 R$ and the crystals contain a racemic mixture. In the case of (II), which is in a chiral space group, the absolute configuration of the molecules is $3 S, 4 S$ or its enantiomorph $3 R, 4 R$. The absence of a strong anomalous scatterer in the crystal does not allow unequivocal determination of the absolute configuration.

In both (I) and (II), the phenyl substituent at atom C4 and the aromatic ring of the isochroman moiety are oriented almost perpendicular to each other. The dihedral angles between the planes of these rings are 84.45 (3) and $75.21(5)^{\circ}$ for (I) and (II), respectively. The non-H atoms of the methoxy groups do not deviate significantly from the planes of the rings to which they are attached, the maximum deviation being 0.215 (2) $\AA$ for atom C440 in (I) and 0.026 (4) $\AA$ for atom O45 in (II). As expected, the methoxycarbonylmethyl substituents are planar. In the molecule of (I), the $\mathrm{C} 31 / \mathrm{C} 32 / \mathrm{O} 30 / \mathrm{O} 31 / \mathrm{C} 310$ plane makes a dihedral angle of $16.95(3)^{\circ}$ with the flat fragment of the isochroman moiety (C5-C10/C1/C4); in the molecule of (II), this angle is $60.06(5)^{\circ}$.

There is no typical H-atom donor system in the molecules of the title compounds, and therefore typical inter- or intramolecular hydrogen bonds cannot form. Only $\mathrm{C}-\mathrm{H} \cdots X$ interactions, usually defined as weak, can be found in the crystal structures of (I) and (II). Analysis of the packing suggests the presence of such interactions in the crystal of (I). There are two weak interactions in which aromatic $\mathrm{C}$ atoms act as $\mathrm{H}$ atom donors, with $\mathrm{O}$ atoms acting as acceptors (Table 2). In one of these bonds, $\mathrm{C} 7-\mathrm{H} 7 \cdots \mathrm{O} 2\left(1-x, \frac{1}{2}+y, \frac{1}{2}-z\right)$, the linked molecules, related via a $2_{1}$ symmetry operation, form

\section{Figure 3}

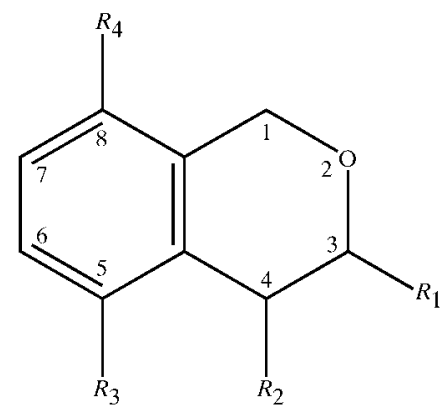

The molecular schemes of previously investigated isochroman derivatives (space groups are also given): (1) $R_{1}=\mathrm{OH}, R_{2}=4$-methoxyphenyl, $R_{3}=\mathrm{OMe}$ and $R_{4}=\mathrm{H}(P \overline{1}$; Palusiak, Małecka, Rybarczyk-Pirek et al., 2003); (2) $R_{1}=\mathrm{OH}, R_{2}=2$,5-dimethoxyphenyl, $R_{3}=\mathrm{H}$ and $R_{4}=\mathrm{OMe}$ $\left(P 2_{1} 2_{1} 2_{1}\right.$; Palusiak et al., 2002a); (3) $R_{1}=\mathrm{OH}, R_{2}=4$-methoxyphenyl, $R_{3}=\mathrm{H}$ and $R_{4}=\mathrm{OMe}\left(P 2_{1}\right.$; Palusiak, Grabowski et al., 2003); (4) $R_{1}=\mathrm{CH}_{2} \mathrm{COOCH}_{3}, R_{2}=3$-methoxyphenyl, $R_{3}=\mathrm{OMe}$ and $R_{4}=\mathrm{H}(P \overline{1}$; Palusiak et al., 2002b). chains. This topological motif corresponds to the first-level graph-set descriptor $C(6)$ (Bernstein et al., 1995). In the second interaction, $\mathrm{C} 46-\mathrm{H} 46 \cdots \mathrm{O} 5(-1+x, y, z), C(7)$ chains, generated from a translation operation along the [100] direction, are formed by adjacent molecules. The crystal structure is therefore stabilized by an infinite three-dimensional network of weak hydrogen bonds. In (II), the number of short contacts (less than $4 \AA$ ) is greater than it is in (I). Nevertheless, none of these interactions can be recognized as hydrogen bonds.

Compound (II) crystallizes in a chiral space group, in spite of its non-stereospecific synthesis in which both trans stereoisomers were obtained (Epsztajn et al., 2001). A similar situation has been found in the cases of two previously examined crystal structures of isochroman derivatives crystallizing in chiral space groups (Palusiak et al., 2002a; Palusiak, Grabowski et al., 2003). The scheme in Fig. 3 shows the correlation between the arrangement of substituents attached to the isochroman moiety and the space group for previously investigated isochroman derivatives. Analysis of the arrangement of the substituents in comparison with their space group suggests that isochroman molecules in which a methoxy group is attached at the 8-position have a tendency to crystallize in a chiral space group. As shown, this effect exists for derivatives containing a hydroxy group at the 3-position, and our results now demonstrate that this group can be replaced by a methoxycarbonylmethyl substituent. It is thus possible to speculate that these observations must be related to advantageous packing of molecules in a chiral space group. In addition, the melting points of both compounds were determined by differential scanning calorimetry measurements. Interestingly, the melting point is considerably higher in the case of (II), being $426.01 \mathrm{~K}$ for (II) and $361.63 \mathrm{~K}$ for (I). Such a large difference cannot be explained solely on the basis of a difference in molecular mass and may, in part, be related to the close $\mathrm{C}-\mathrm{H} \cdots \mathrm{O}$ interactions observed in (II).

\section{Experimental}

The syntheses of (I) and (II) were described by Epsztajn et al. (2001). Single crystals were obtained by slow evaporation from methanol solutions at room temperature.

\section{Compound (I)}

$\begin{array}{ll}\text { Crystal data } & \\ \mathrm{C}_{20} \mathrm{H}_{22} \mathrm{O}_{5} & D_{x}=1.332 \mathrm{Mg} \mathrm{m} \\ M_{r}=342.38 & \text { Mo } \alpha \alpha \text { radiation } \\ \text { Monoclinic, } P{ }_{1} / c & \text { Cell parameters } \\ a=5.6432(3) \AA & \text { reflections } \\ b=14.5521(8) \AA & \theta=2.4-25.9^{\circ} \\ c=20.9417(12) \AA & \mu=0.10 \mathrm{~mm}^{-1} \\ \beta=96.799(7)^{\circ} & T=173(2) \mathrm{K} \\ V=1707.65(16) \AA^{3} & \text { Prism, colourless } \\ Z=4 & 0.5 \times 0.5 \times 0.4 \mathrm{r} \\ \text { Data collection } & \\ \text { Stoe IPDS diffractometer } & \\ \varphi \text { scans } & R_{\text {int }}=0.057 \\ 17008 \text { measured reflections } & \theta_{\text {max }}=25.9^{\circ} \\ 3267 \text { independent reflections } & h=-6 \rightarrow 6 \\ \text { 2607 reflections with } I>2 \sigma(I) & k=-17 \rightarrow 17 \\ & l=-25 \rightarrow 25\end{array}$




\section{Refinement}

Refinement on $F^{2}$

$R\left[F^{2}>2 \sigma\left(F^{2}\right)\right]=0.033$

$w R\left(F^{2}\right)=0.088$

$S=1.03$

3267 reflections

229 parameters

$\mathrm{H}$-atom parameters constrained

$$
\begin{gathered}
w=1 /\left[\sigma^{2}\left(F_{o}^{2}\right)+(0.051 P)^{2}\right. \\
+0.1166 P] \\
\text { where } P=\left(F_{o}^{2}+2 F_{c}^{2}\right) / 3^{\prime} \\
(\Delta / \sigma)_{\max }=0.001 \\
\Delta \rho_{\max }=0.26 \AA^{-3} \\
\Delta \rho_{\min }=-0.13 \mathrm{e}^{-3}
\end{gathered}
$$

Table 1

Selected geometric parameters $\left(\AA{ }^{\circ}{ }^{\circ}\right)$ for (I).

\begin{tabular}{lclr}
\hline $\mathrm{C} 32-\mathrm{O} 30$ & $1.2034(16)$ & $\mathrm{O} 2-\mathrm{C} 1$ & $1.4309(14)$ \\
$\mathrm{C} 32-\mathrm{O} 31$ & $1.3377(15)$ & $\mathrm{O} 2-\mathrm{C} 3$ & $1.4385(13)$ \\
& & & \\
$\mathrm{O} 2-\mathrm{C} 3-\mathrm{C} 4$ & $110.34(9)$ & $\mathrm{C} 1-\mathrm{O} 2-\mathrm{C} 3$ & $113.60(8)$ \\
& & & \\
$\mathrm{O} 2-\mathrm{C} 3-\mathrm{C} 4-\mathrm{C} 10$ & $50.63(12)$ & $\mathrm{O} 30-\mathrm{C} 32-\mathrm{O} 31-\mathrm{C} 310$ & $-5.8(2)$ \\
$\mathrm{C} 31-\mathrm{C} 3-\mathrm{C} 4-\mathrm{C} 41$ & $158.56(9)$ & $\mathrm{C} 1-\mathrm{O} 2-\mathrm{C} 3-\mathrm{C} 4$ & $-65.25(12)$ \\
$\mathrm{C} 10-\mathrm{C} 9-\mathrm{C} 1-\mathrm{O} 2$ & $-9.41(16)$ & $\mathrm{C} 440-\mathrm{O} 44-\mathrm{C} 44-\mathrm{C} 45$ & $3.04(18)$ \\
$\mathrm{C} 9-\mathrm{C} 10-\mathrm{C} 4-\mathrm{C} 41$ & $104.65(12)$ & $\mathrm{C} 50-\mathrm{O} 5-\mathrm{C} 5-\mathrm{C} 6$ & $-0.24(16)$ \\
$\mathrm{C} 9-\mathrm{C} 10-\mathrm{C} 4-\mathrm{C} 3$ & $-18.99(14)$ & &
\end{tabular}

Table 2

Hydrogen-bonding geometry $\left(\AA,^{\circ}\right)$ for $(\mathrm{I})$.

\begin{tabular}{lllll}
\hline$D-\mathrm{H} \cdots A$ & $D-\mathrm{H}$ & $\mathrm{H} \cdots A$ & $D \cdots A$ & $D-\mathrm{H} \cdots A$ \\
\hline $\mathrm{C} 7-\mathrm{H} 7 \cdots \mathrm{O} 2^{\mathrm{i}}$ & 0.95 & 2.46 & $3.354(1)$ & 156 \\
$\mathrm{C} 46-\mathrm{H} 46 \cdots \mathrm{O} 5^{\mathrm{ii}}$ & 0.95 & 2.45 & $3.320(1)$ & 152 \\
\hline
\end{tabular}

Symmetry codes: (i) $1-x, \frac{1}{2}+y, \frac{1}{2}-z$; (ii) $x-1, y, z$.

\section{Compound (II)}

\section{Crystal data}

$$
\begin{aligned}
& \mathrm{C}_{21} \mathrm{H}_{24} \mathrm{O}_{6} \\
& M_{r}=372.4 \\
& \text { Orthorhombic, } P 22_{1} 22_{1} 2_{1} \\
& a=6.4796(4) \AA \\
& b=17.9680(9) \AA \\
& c=16.0587(9) \AA \\
& V=1869.64(18) \AA^{3} \\
& Z=4 \\
& D_{x}=1.323 \mathrm{Mg} \mathrm{m}^{-3}
\end{aligned}
$$

\section{Data collection}

Stoe IPDS diffractometer

\section{$\varphi$ scans}

13101 measured reflections

2076 independent reflections

1862 reflections with $I>2 \sigma(I)$

\section{Refinement}

Refinement on $F^{2}$

$R\left[F^{2}>2 \sigma\left(F^{2}\right)\right]=0.028$

$w R\left(F^{2}\right)=0.068$

$S=1.03$

2076 reflections

256 parameters
Mo $K \alpha$ radiation

Cell parameters from 8000 reflections

$\theta=2.8-25.9^{\circ}$

$\mu=0.10 \mathrm{~mm}^{-1}$

$T=173$ (2) $\mathrm{K}$

Cut block, colourless

$0.3 \times 0.2 \times 0.2 \mathrm{~mm}$

$R_{\text {int }}=0.031$

$\theta_{\text {max }}=25.9^{\circ}$

$h=-7 \rightarrow 7$

$k=-20 \rightarrow 21$

$l=-19 \rightarrow 19$

$\mathrm{H}$-atom parameters constrained

$w=1 /\left[\sigma^{2}\left(F_{o}^{2}+(0.0497 P)^{2}\right]\right.$

where $P=\left(F_{o}^{2}+2 F_{c}^{2}\right) / 3^{\prime}$

$(\Delta / \sigma)_{\max }<0.001$

$\Delta \rho_{\max }=0.20 \mathrm{e}^{-3}$

$\Delta \rho_{\min }=-0.11 \mathrm{e} \AA^{-3}$
Table 3

Selected geometric parameters $\left(\AA,^{\circ}\right)$ for (II).

\begin{tabular}{lrlr}
\hline $\mathrm{C} 1-\mathrm{O} 2$ & $1.424(2)$ & $\mathrm{C} 32-\mathrm{O} 30$ & $1.205(2)$ \\
$\mathrm{C} 3-\mathrm{O} 2$ & $1.433(2)$ & $\mathrm{C} 32-\mathrm{O} 31$ & $1.348(2)$ \\
& & & \\
$\mathrm{O} 2-\mathrm{C} 3-\mathrm{C} 4$ & $110.18(13)$ & $\mathrm{C} 1-\mathrm{O} 2-\mathrm{C} 3$ & $111.50(12)$ \\
& & & \\
$\mathrm{O} 2-\mathrm{C} 1-\mathrm{C} 9-\mathrm{C} 10$ & $-18.2(2)$ & $\mathrm{C} 3-\mathrm{C} 4-\mathrm{C} 10-\mathrm{C} 9$ & $-13.6(2)$ \\
$\mathrm{C} 4-\mathrm{C} 3-\mathrm{O} 2-\mathrm{C} 1$ & $-69.08(17)$ & $\mathrm{C} 7-\mathrm{C} 8-\mathrm{O} 8-\mathrm{C} 80$ & $-3.2(2)$ \\
$\mathrm{O} 2-\mathrm{C} 3-\mathrm{C} 4-\mathrm{C} 10$ & $46.65(18)$ & $\mathrm{O} 30-\mathrm{C} 32-\mathrm{O} 31-\mathrm{C} 310$ & $-2.1(3)$ \\
$\mathrm{C} 31-\mathrm{C} 3-\mathrm{C} 4-\mathrm{C} 41$ & $-70.87(17)$ & $\mathrm{C} 43-\mathrm{C} 42-\mathrm{O} 42-\mathrm{C} 420$ & $-3.1(2)$ \\
$\mathrm{C} 41-\mathrm{C} 4-\mathrm{C} 10-\mathrm{C} 9$ & $-136.37(15)$ & $\mathrm{C} 44-\mathrm{C} 45-\mathrm{O} 45-\mathrm{C} 450$ & $-3.1(3)$ \\
& & &
\end{tabular}

All $\mathrm{H}$ atoms were placed in idealized positions and constrained to ride on their parent atoms, with $\mathrm{C}-\mathrm{H}$ distances in the range 0.93 $0.98 \AA$. For methoxy $\mathrm{H}$ atoms, $U_{\text {iso }}(\mathrm{H})$ values were taken to be $1.5 U_{\text {eq }}(\mathrm{C})$; for all other $\mathrm{H}$ atoms, $U_{\text {iso }}(\mathrm{H})$ values were set at $1.2 U_{\text {eq }}(\mathrm{C})$. In the refinement of (II), data were merged using MERG4 in SHELXL97, according to the standard procedure for X-ray Mo $K \alpha$ measurements of chemical compounds without heavy atoms.

For both compounds, data collection: IPDS Software (Stoe \& Cie, 1998); cell refinement: IPDS Software; data reduction: IPDS Software; program(s) used to solve structure: SHELXS97 (Sheldrick, 1997); program(s) used to refine structure: SHELXL97 (Sheldrick, 1997); molecular graphics: PLATON (Spek, 1990); software used to prepare material for publication: PARST (Nardelli, 1996).

Supplementary data for this paper are available from the IUCr electronic archives (Reference: SX1129). Services for accessing these data are described at the back of the journal.

\section{References}

Bernstein, J., Davis, R. E., Shimoni, L. \& Chang, N.-L. (1995). Angew. Chem. Int. Ed. Engl. 34, 1555-1573.

Cremer, D. \& Pople, J. A. (1975). J. Am. Chem. Soc. 97, 1354-1358.

Epsztajn, J., Bieniek, A., Kowalska, J. A. \& Malinowski, Z. (2001). Tetrahedron Lett. 42, 9293-9295.

Moore, H. W. (1977). Science, 197, 527-532.

Moore, H. W. \& Czerniak, R. (1981). Med. Res. Rev. 1, 249-280.

Nardelli, M. (1983). Acta Cryst. C39, 1141-1142.

Nardelli, M. (1996). J. Appl. Cryst. 29, 296-300.

Palusiak, M., Grabowski, S. J., Epsztajn, J. \& Kowalska, J. A. (2003). Acta Cryst. E59, o2000-02002.

Palusiak, M., Małecka, M., Grabowski, S. J., Epsztajn, J., Bieniek, A. \& Kowalska, J. A. (2002a). Acta Cryst. E58, o620-0622.

Palusiak, M., Małecka, M., Grabowski, S. J., Epsztajn, J., Bieniek, A. \& Kowalska, J. A. (2002b). Acta Cryst. E58, o1188-o1189.

Palusiak, M., Małecka, M., Rybarczyk-Pirek, A., Epsztajn, J., Bieniek, A. \& Kowalska, J. A. (2003). Acta Cryst. E59, o11-o13.

Sheldrick, G. M. (1997). SHELXL97 and SHELXS97. University of Göttingen, Germany.

Spek, A. L. (1990). Acta Cryst. A46, C-34.

Stoe \& Cie (1998). IPDS Software. Version 2.89. Stoe \& Cie GmbH, Darmstadt, Germany. 